\title{
Türkiye’de Muhasebecilerin Mesleki Rollerini Algılamaları
}

\author{
Hüseyin DALĞAR* \\ Ömer TEKŞEN ${ }^{* *}$
}

\section{ÖZET}

Zaman içerisinde gerek mesleki rekabet gerekse mükelleflerin beklentilerinin farklılaşması nedeniyle muhasebe meslek mensupları yasal görev ve sorumluluklarının yanı sira birçok farklı görevi de üstlenmeye başlamıştır. Bu durum, zamanla Türkiye'de meslek mensuplarının mesleki rolüyle ilgili algıların değişmesine yol açmıştır.

Bu çalışmada, Türkiye'de faaliyette bulunan muhasebe meslek mensuplarının mesleki rollerini nasıl algıladıklarını ve demografik özellikleri ile mesleki rol algıları arasında ilişki olup olmadığını tespit etmek amaçlanmaktadır. Anket yoluyla elde edilen verilere göre muhasebecilerin mesleki rollerini Mali Danışmanlık, Yasal Yükümlülükleri Yerine Getirme ve Asli Görevi Dışındaki Işsler olmak üzere üç boyutta algıladıkları tespit edilmiştir. Ayrıca meslek mensuplarının medeni hali, eğitim düzeyi, mesleki unvanı ve gelir düzeyi ile mesleki rollerini algılamaları arasında anlamlı bir ilişki olduğu sonucuna ulaşılmıştır.

Anahtar Kelimeler: Serbest Muhasebeci Mali Müşavir, Rol Algılaması, Türkiye.

JEL Sinıflandirması: M40, M41.

\section{Occupational Role Perceptions of Accountants In Turkey}

\section{ABSTRACT}

Whether due to occupational competition or the differentiation of expectancies of their clients, as time passes, accountants have begun to undertake many different duties beyond their legal obligations and responsibilities. Over time, this situation has caused changes in the perception of the occupational roles of accountants in Turkey.

The purpose of this study is to find out how active accountants in Turkey perceive their occupational duties and whether a correlation exists between their perception and demographic properties. According to data obtained through surveys, it has been established that accountants perceive their occupational roles in three categories: Financial Consulting, Fulfilling Legal Obligations, and Performing Non-Essential Duties. Furthermore, it has been concluded that there is a significant correlation between accountants' marital status, level of education, job title, and income level and their perception of their occupational roles.

Keywords: Certified Public Accountant (CPA), Role perception, Turkey.

Jel Classification: M40, M41.

\footnotetext{
* Doç. Dr. Hüseyin Dalğar, Mehmet Akif Ersoy Üniversitesi, İktisadi ve İdari Bilimler Fakültesi, hdalgar@mehmetakif.edu.tr

${ }^{* *}$ Doç. Dr. Ömer Tekşen, Mehmet Akif Ersoy Üniversitesi, İktisadi ve İdari Bilimler Fakültesi, omerteksen@mehmetakif.edu.tr
} 


\section{GíRiș}

Türkiye'de muhasebe meslek mensubunun görevleri 3568 Sayılı Türkiye Serbest Muhasebeci ve Mali Müşavirlik Kanunu'nda açıç̧a belirtilmiştir. Muhasebe mesleğinde mükellefin hizmetten duyduğu tatmini etkileyen önemli faktörlerden biri muhasebe mesleği ile ilgili görevin önem derecesi ve bunun karşılanma düzeyindeki yeterliliktir. Her ne kadar 3568 sayılı kanunda muhasebe meslek mensuplarının görevleri ayrıntılı bir şekilde belirtilmiş olsa da, mükelleflerin muhasebe meslek mensuplarından kanundaki görevlerin dışındaki işler noktasında talepte bulunması meslek mensubu açısından rol çatışmasını meydana getirmektedir. Rol çatışması muhasebe işlerinin yapıldığı muhasebe bürolarında sık sık karşılaşılan önemli sorunlardan birisidir.

Muhasebe bürolarında karşılaşılan rol çatışması, aynı anda birden fazla fonksiyonu yerine getirme durumunda olan muhasebe meslek mensubunun rol gereklerinden birisine, diğerlerine oranla daha fazla uymak zorunda kalmasıdır. Bu rol çatışması, meslekte iç çatışmalara yol açmakta, meslek mensubunun geriliminin yükselmesine neden olmakta, iş tatminini düşürmekte, meslek mensubunun kendisine ve mesleğine olan güveninin azalmasına neden olmaktadır. Muhasebe meslek mensuplarının karşılaştıkları bu rol çatışmaları zamanla rol belirsizliklerine dönüşmektedir. Dolayısıyla meslek mensupları zamanla çevrenin de etkisi ile mesleğiyle ilgili ne yapacağını tam olarak bilememekte ve mesleki rollerinde algılama farklılığ 1 oluşmaktadır. Muhasebe meslek mensuplarının bu mesleki rollerindeki algılama farklılıkları zamanla iş tatminsizliğine, iş gerilimine ve mükellefi kaybetme korkusuyla kendine güvensizliğe dönüşmektedir. Dolayısıyla her ne kadar kanunda muhasebe meslek mensuplarının görev alanları açıkça belirtilmiş olsa da uygulamadaki görev sınırlarının iyi çizilememiş olması, mükellefin meslek mensubundan beklentilerinin açık olmaması, muhasebe meslek mensubunda mesleki rol algılamasının değişmesine sebep olmaktadır. Diğer taraftan Türkiye'de son zamanlarda yeni kurulan işletmelerin sayısının artmasıyla birlikte muhasebe meslek mensuplarının bu artan pastadan fazla dilim alma gayretiyle kanunda belirtilen muhasebe mesleği görevlerinin dışında ek bir takım görevlerin yapılması da gündeme gelmektedir. Bu bağlamda meslek mensupları, müşteri memnuniyeti kaygısı ile kendi görev alanlarına ilaveten mükellefin bazı kişisel iş ve işlemleri ile ilgili taleplerini de kabul ederek, yasayla tanımlanmış görevleri dışında bir takım rolleri de üstlenebilmektedirler.

Muhasebe meslek mensuplarının zaman içerisinde mesleki rollerinde ne gibi değişmeler meydana geliyor, daha da önemlisi mesleki rol algıları ne yönde şekilleniyor ve bu algılarında belirleyici unsurlar nelerdir sorularına yanıt vermek oldukça güçtür. $\mathrm{Bu}$ nedenle gerek ilgili literatüre katkı sağlamak gerekse muhasebe meslek mensuplarının mesleki rol algılarını gözden geçirmelerine imkan vermek açısından bu çalışma faydalı olacaktır. 
Bu çalışmada, Türkiye'de faaliyette bulunan muhasebe meslek mensuplarının mesleki rollerinin zaman içerisinde nasıl değişiklik gösterdiği ve meslek mensubunun gözünde bu değişikliklerin nasıl algılandığının tespit edilmesi amaçlanmaktadır. Bu doğrultuda öncelikle rol ve algılama kavramları üzerinde durulmuş, daha sonra Türkiye'nin tüm bölgelerinde yapılan araştırma hakkında ayrıntılı bilgiler verilmiştir. Araştırma kısmında da öncelikle anket ve örneklem ile yöntem hakkında bilgiler verilmiş daha sonra araştırmanın analiz sonuçları ayrıntılı bir şekilde açıklanarak yorumlanmıştır.

\section{ROL VE ALGILAMA}

Rol, bireyin bulunduğu statü sınırları içinde neyi yapabileceği veya neyi yapamayacağı şeklindeki belirlenmiş davranışlarının toplamıdır. Bireyin bir sosyal grup içinde hakları ve yükümlülükleri belirlendiğinde, onun aynı zamanda rolü de belirlenmiş olmaktadır. Bireyin aynı anda birden fazla rolü gerçekleştirmek durumunda kalması ve bu rollerden birini diğerine oranla daha fazla benimsemesi, üstlendiği rol ile kişilik özelliklerinin uymaması gibi durumlarda rol çatışması meydana gelmektedir. Rolün açıkça tanımlanmadığı veya üstlenilen rolün yeterince bilinmediği durumlarda rol belirsizliği görülmektedir. Çalışan kişi için sorumlulukların genişliği, otoritesinin sınırları, işletme kuralları, iş güvenliği konularında açıklık olmaması gibi nedenler rol belirsizliğini doğurmaktadır (Gümüştekin ve Öztemiz, 2005: 274).

Bireylerin işinde nelere yetkisinin olup nelere yetkisinin olmadığını bilmemesi; işiyle ilgili olarak açık, net ve planlı hedeflerini ve ulaşması gereken standartların olmaması; işinde zamanını en uygun şekilde kullandığından emin olmaması; işiyle ilgili sorumluluklarının neler olduğunu bilmemesi; işinde kendisinden beklenen şeylerin neler olduğunu tam ve kesin olarak bilmemesi; görevinin ne olduğuna dair kendisine bildirilen şeylerin açık olmaması rol belirsizliğini artıran unsurlardır (Ceylan ve Ulutürk, 2006:49).

Algılama, bireyin çevreden kendisine doğru akan bilgileri alma, düzenleme ve yorumlama sürecidir (Erdoğan, 1996: 2). Bireylerin algılamaları yaşam biçimlerine, kültürlerine, inanç sistemlerine, değerlerine ve kişilik özelliklerine göre değişiklik gösterir. Bu durumda algılanan ifadesi "bireyin çevresini algılaması" ile ilgili bir kavramdır. Örgütün birey tarafından görünüşü veya örgütteki bir takım olayların bireyler tarafindan algılanmaları farklılıklar gösterecektir. Bir bireyin olumlu olarak algıladığı uygulamalar, diğer bazı bireyler tarafından olumsuz olarak algılanıp yorumlanabilecektir (Eisenberger vd. 1986: 502). Günümüzde belli bir örgütte çalışan birey, zamanının büyük bir bölümünü iş ortamında geçirmekte ve belli amaçları gerçekleştirmek üzere kendisinden beklenen rolleri ve görevleri yerine getirmektedir. $\mathrm{Bu}$ durum örgüt ortamında meydana gelen "örgütsel stres" kavramını ortaya çıkarmaktadır (Aydın, 2002: 41). 
Örgüt içinde rol, belli bir makamda bulunan bireyden beklenen davranıştır. Makamların sınıflandırılması ve işlerin çözümlenmesinde rol ve statü gerçekleri esas alınır. Rol davranışları; rol algılaması ve rol beklentileri tarafından biçimlendirilir. Rol algılaması; bir bireyin belirli bir durumda nasıl hareket edeceği konusundaki görüşüdür. Rol beklentisi ise; çevremizde bulunan rol gönderenlerin rol davranışını gösterecek kişiden beklentileridir. Rol gönderen kaynaklardan birisi görevdir. Görev tanımlamaları, göreve ilişkin yetki ve sorumlulukları ortaya koyan yasa, tüzük, yönetmelik, genelge, görev ve iş listeleridir. Kişinin bunlara karşı tutumu, görev ve görev algısını belirler. Rolün oluşumunu etkileyen ikinci kaynak bireyin kişiliği ve yeterlikleridir. Birey, kişisel yeterliklerinin izin verdiği ölçüde rol algılamasında bulunabilir. Rolün oluşumunu belirleyen üçüncü kaynak ise çevredir. Çevrenin çeşitli yapılara bağlı özellikleri, çevreden gelen rol beklentilerinin farklılaşmasına neden olur. Çevre role olduğu kadar bireye de etki ederek, rol oluşumunda güçlü bir etkiye sahip olur. Statüyü, rolün önemine verilen değer olarak tanımladığımızda; örgütlerde statüyü belirleyenin de örgüt içi roller olduğu sonucuna varabiliriz (Başaran, 1991: 132, Başar, 1998: 23).

\section{TÜRKIYE'DEKİ MUHASEBECILERIN GÖREVLERİ ILEE MUHASEBE MESLEĞİNDE GÖRÜLEN ROL DEĞIŞSiKLIKLERİ}

Ülkemizdeki muhasebe uygulamaları uzun yıllar, vergi muhasebeciliği şeklinde gelişmiştir. $\mathrm{Bu}$ anlayış, meslek örgütlenmesine bağlı olarak muhasebe mesleğinin profesyonelleşmesine, sermaye piyasalarının gelişimine, işletmelerin kurumsallaşmasına ve işletme yönetimi anlayışındaki dönüşüme bağlı olarak değişmektedir (Nalbantoğlu, 2003 s.3).

Muhasebe meslek mensupları işletme ile ilgili kişi ve kuruluşların ihtiyaç duyduğu mali nitelikteki bilgileri üretip bunları raporlar aracıllğı ile ilgili kesinlere sunma görevini üstlenmektedirler. Muhasebe meslek mensuplarının görevleri yasa ile belirlenmiş olmakla birlikte, zaman içerisinde ekonomik, sosyal ve teknolojik alanlardaki gelişmelerin etkisiyle ürettikleri bilgilerin kapsamı genişlemekte ve nitelikleri değişmektedir (Marşab, 1996: 119).

Meslek mensuplarının 3568 sayılı yasa ile belirlenen görevleri şunlardır;

Muhasebecilik ve malî müşavirlik mesleğinin konusu gerçek ve tüzelkişilere ait teşebbüs ve işletmelerin;

- $\quad$ Genel kabul görmüş muhasebe prensipleri ve ilgili mevzuat hükümleri gereğince, defterlerini tutmak, bilanço, kâr-zarar tablosu ve beyannameleri ile diğer belgelerini düzenlemek ve benzeri işleri yapmak.

- Muhasebe sistemlerini kurmak, geliştirmek, işletmecilik, muhasebe, finans, malî mevzuat ve bunların uygulamaları ile ilgili işlerini düzenlemek veya bu konularda müşavirlik yapmak. 
- Yukarıdaki bentte yazılı konularda, belgelerine dayanılarak, inceleme, tahlil, denetim yapmak, malî tablo ve beyannamelerle ilgili konularda yazılı görüş vermek, rapor ve benzerlerini düzenlemek, tahkim, bilirkişilik ve benzeri işleri yapmaktır.

Her ne kadar muhasebe meslek mensuplarının görevleri yasa ile yukarıdaki şekilde belirlenmiş olsa da; uygulamada bilgi kullanıcılarından gelen talepler doğrultusunda meslek mensuplarının rolleri zamanla değişikliğe uğramıştır. Muhasebecilik mesleğinin fonksiyonu; yalnızca kanunla tanımlanan görevlerini yapmanın ötesinde, tüm ilişkili taraflardan gelen taleplere yanıt veren, müşterilerinin mali konulardaki her türlü bilgi ihtiyacını karşılayan, devlete karşı tüm yükümlülüklerini yerine getirmelerine yardımcı olan bir şekle dönüşmüştür. $\mathrm{Bu}$ doğrultuda son yıllarda muhasebe meslek mensuplarının mesleğin konusunun dışında; vergi idaresi, sosyal güvenlik kurumu, meslek odaları ve diğer tüm resmi kurumlarla ilişkili her türlü iş ve işlemlerini müşterileri adına aktif olarak takip ettikleri veya bu iş ve işlemlerin gerçekleştirilmesine yardımcı oldukları görülmektedir.

\section{ARAŞTIRMANIN METODOLOJISİ}

\subsection{Anket ve Örneklem}

Muhasebe meslek mensupları bazen asli rollerinden uzaklaşarak zamanlarının önemli bir bölümünü müşterilerinin yukarıda belirtilen kişisel iş ve işlemlerine harcamak durumunda kalmaktadirlar. Hatta bu durum zamanla meslek mensupları tarafından kanıksanmakta ve asli mesleki rolleri olarak da algılanmaktadır. Bu bağlamda çalışmada meslek mensuplarının kendi mesleki rollerini nasıl algıladıklarını ve bu algılama ile demografik özellikleri arasında ilişkisinin olup olmadığını ortaya koymak amaçlanmaktadır.

$\mathrm{Bu}$ amaç doğrultusunda deneyimli muhasebe meslek mensuplarından oluşan bir grup ile anket sorularının belirlenmesi için bir çalışma toplantısı yapılmıştır. Bu toplantıda bulunan muhasebe meslek mensuplarının yaşadığı tecrübeleri doğrultusunda öncelikle uygulamada karşılaştıkları tüm müşteri talepleri ve gerçekleştirdikleri işler belirlenmiştir. Daha sonra çalışma toplantısında belirlenen müşteri talepleri ve muhasebe meslek mensuplarının gerçekleştirdikleri işlere göre 21 sorudan oluşan 5'li likert ölçeğinde ( $1=$ Kesinlikle Katılmıyorum, 5=Kesinlikle Katılıyorum) anket formu oluşturulmuştur. Ayrıca anket formunun ikinci bölümünde ise muhasebe meslek mensuplarının mesleki rol algılarında belirleyici olabileceği düşünülen bazı demografik özelliklerine yer verilmiştir. Demografik sorular bölümünde muhasebe meslek mensuplarının hangi özelliklerine yer verileceği konusunda deneyimli muhasebe meslek mensuplarının tecrübe ve gözlemlerine göre öne sürdüğu şu düşünce ve varsayımlardan yola çıkılmıştır. 
Deneyimli muhasebe meslek mensuplarının görüşlerine göre; erkekler ile kadınlar arasında birçok konuda olduğu gibi mesleğe bakış açısından da farklılıklar bulunmaktadır. Bireylerin evlendikten sonra ve yaşı ilerledikçe artan ailevi ve sosyal sorumluluklarına bağlı olarak sorumluluk duyguları ve mesleğine bakışı değişebilmektedir. Diğer taraftan her meslekte olduğu gibi muhasebe mesleğinde de bireylerin eğitim düzeyleri mesleki rollerini algılamalarında farklılık meydan getirebilmektedir. Muhasebe meslek mensuplarının eğitim düzeyleri arttıkça mesleki nitelikleri ve dolayısıyla mesleklerine bakışları gelişmektedir. Aynı şekilde meslek mensuplarının meslekte çalışma sürelerini ifade eden mesleki deneyimleri arttıkça mesleğe ilk başladıkları yıllara göre bakış açılarında ve mesleki algılamalarında da değişiklikler meydana gelebilmektedir. Yine muhasebe meslek mensuplarının görüşlerine göre gelir seviyesi yüksek olan meslek mensuplarının genellikle daha büyük işletmelere hizmet sundukları ve bu nedenle de niteliği daha yükssek işlerle uğraştıkları düşünülmektedir. Son olarak muhasebe meslek mensuplarının işyeri sahibi olması veya bir muhasebe bürosunda çalışan pozisyonunda olmalarının da sorumluluk alma açısından farklı olduğu, buna bağlı olarak da mesleki rol algılamalarının farklı olacağı tahmin edilmektedir.

Araştırmanın evrenini Türkiye'de faaliyet gösteren muhasebe meslek mensupları oluşturmaktadır. Türkiye'de toplam 99.863 serbest muhasebeci ve serbest muhasebeci mali müşavir bulunmaktadır (turmob.org.tr, 17 Ocak 2017). \% 95 anlamlılık düzeyinde 99.863 kişilik ana kütle için $\pm 0,05$ örneklem hatası $(\mathrm{p}=0,5 ; \mathrm{q}=0,5)$ ile minimum düzeyde örneklem sayısı 383 olarak hesaplanmaktadır. (Yazıcığlu ve Erdoğan, 2004: 50).

Bu kapsamda araştırmada 409 adet anket, İstanbul, Ankara ve İzmir gibi büyük şehirler öncelikli olmak üzere 27 farklı şehirde faaliyet gösteren muhasebe meslek mensuplarının yüz yüze görüşme yöntemiyle doldurtulmuştur.

\subsection{Yöntem}

Deneyimli muhasebe meslek mensuplarının görüşleri alınarak oluşturulan ve 21 ifadeden oluşan anketler Türkiye'deki tesadüfi olarak seçilen 27 ildeki yine tesadüfi olarak seçilen 409 muhasebe meslek mensupları tarafından doldurulmuştur. Ayrıca anketlerde muhasebe meslek mensuplarının demografik özelliklerine yönelik 7 ifadeden oluşan soruları da cevaplamaları istenmiştir. Anketler muhasebecilerin ofislerine gitmek suretiyle yüz yüze görüşerek uygulanmıştır. Anketlerden elde edilen veriler SPSS programı yardımıyla analiz edilmiştir. Bu kapsamda, sırasıyla güvenilirlik testi, frekans testi, faktör analizi ve ANOVA analizi yapılmıştır. Ayrıca ANOVA testi ile anlamlı ilişki tespit edilen değişkenlerde ilişkinin şeklini açıklayabilmek amacıyla Post Hoc (Tukey) testi yapılmıştır.

Araştırmada muhasebe meslek mensuplarının mesleki rollerini belirlemenin yanı sıra mesleki rollerini nasıl algıladıkları noktasında bazı demografik özelliklerinin 
belirleyici olup olmadığı sorgulanmıştır. Bu bağlamda iki temel hipotez oluşturulmuştur.

H0: Muhasebe meslek mensuplarının demografik özellikleri ile mesleki rollerini algılamaları arasında anlamlı bir ilişki yoktur.

H1: Muhasebe meslek mensuplarının demografik özellikleri ile mesleki rollerini algılamaları arasında anlamlı bir ilişki vardır.

\subsection{Analiz ve Bulgular}

\subsubsection{Betimsel Analiz}

Araştırma kapsamında anket uygulanan muhasebe meslek mensuplarının demografik özelliklerine ilişkin bulguların frekans ve yüzde dağılımları Tablo 1'de verilmektedir.

Tablo 1. Muhasebecilerin Demografik Özellikler (n:409)

\begin{tabular}{|c|c|c|c|}
\hline & & Frekans & $\%$ \\
\hline \multirow[t]{2}{*}{ Cinsiyet } & Erkek & 310 & 55,8 \\
\hline & Kadın & 99 & 24,2 \\
\hline \multirow[t]{2}{*}{ Medeni Hal } & Bekar & 102 & 24,9 \\
\hline & Evli & 307 & 75,1 \\
\hline \multirow[t]{3}{*}{ Yaş } & $20-35$ aras1 & 197 & 48,2 \\
\hline & $36-50$ aras1 & 154 & 37,7 \\
\hline & 51 ve üzeri & 58 & 14,1 \\
\hline \multirow[t]{4}{*}{ Ĕgitim Düzeyi } & Lise & 60 & 14,7 \\
\hline & Ön Lisans & 46 & 11,2 \\
\hline & Lisans & 286 & 69,9 \\
\hline & Lisans Üstü & 17 & 4,2 \\
\hline \multirow[t]{2}{*}{ Mesleki Unvanı } & SM & 76 & 18,6 \\
\hline & SMM & 333 & 81,4 \\
\hline \multirow[t]{3}{*}{ Mesleki Deneyim } & $0-10$ y1l aras1 & 180 & 44,0 \\
\hline & $11-20$ y1l aras1 & 142 & 34,7 \\
\hline & 21 yıl ve üzeri & 87 & 21,3 \\
\hline \multirow[t]{2}{*}{ Aylık Gelir Düzeyi (TL) } & 5.000 TL'ye kadar & 344 & 83,6 \\
\hline & 5.000 TL ve üzeri & 65 & 16,4 \\
\hline \multirow[t]{2}{*}{ İşyerindeki Pozisyonu } & İşyeri Sahibi & 327 & 80,0 \\
\hline & Çalışan & 82 & 20,0 \\
\hline
\end{tabular}

Demografik veriler katılımcıların cinsiyet, medeni hal, yaş, eğitim düzeyi gibi kişisel özellikleri ile unvan, deneyim, gelir düzeyi ve işyerindeki pozisyonu gibi mesleki özelliklerini toplu olarak görmemizi sağlamaktadır.

\subsubsection{Güvenilirlik ve Faktör Analizi}

Ankette yer alan çok sayıdaki sorunun faktörlere ayrılmasıyla daha az sayıda değişkenle çalışmak ve değişkenler arasında daha anlamlı ilişkiler kurmak mümkün olabilecektir. Bu amaçla faktör analizi yapılmadan önce araştırmada kullanılan anketin 
içsel tutarlılığı [Cronbach alpha (x)] 0,887 olarak hesaplanmıştır. Cronbach alpha değeri 0,70'den büyük olduğu için muhasebecilerin mesleki rol algılarına ilişkin uygulanan ve 21 ifadeden oluşan anketteki veriler analiz için güvenilir kabul edilmiştir. Ayrıca faktör analizi sonucunda tüm faktör yükleri 0,40 'dan daha büyük olduğu için istatistiksel olarak da anlamlıdır (Nunnally and Bernstein, 1994). 21 sorudan oluşan ve içsel tutarlılığı oldukça yüksek çıkan anket soruları 3 faktör altında gruplanmıştır. Tablo 2, oluşturulan faktörleri, faktör yüklerini ve Cranbach alpha değerlerini ve ifadelere verilen cevapların ortalamalarını göstermektedir.

Tablo 2. Muhasebe Meslek Mensuplarının Mesleki Rollerini Algılamalarıyla İlgili Faktörlerin Yükleri

\begin{tabular}{|c|c|c|c|c|}
\hline FAKTÖRLER & \begin{tabular}{c|c} 
Faktör \\
Ăğırlıkları
\end{tabular} & $\begin{array}{l}\text { Varyans } \\
\text { Yüzdesi }\end{array}$ & Alfa & Ort. \\
\hline Faktör 1: Mali Danışmanlık Rolü & & 25,587 & 0,873 & \\
\hline $\begin{array}{l}\text { Müşterilerime işletme sermayesi yönetimine ilişkin kararlarında destek } \\
\text { vermek }\end{array}$ & 0,775 & & & 3,6822 \\
\hline Müşterilerimin nakit yönetimi ile ilgili kararlarına destek vermek & 0,742 & & & 3,4597 \\
\hline $\begin{array}{l}\text { Müşterilerime kar planlaması ve karlılığı artırmaya yönelik çalışmalarında } \\
\text { yardımcı olmak }\end{array}$ & 0,727 & & & 3,7848 \\
\hline $\begin{array}{l}\text { Müşterilerimin operasyonel bilgilerini analiz etme ve yorumlamalarına } \\
\text { yardımcı olmak }\end{array}$ & 0,721 & & & 3,4694 \\
\hline $\begin{array}{l}\text { Müşterilerimin maliyet hesaplama ve azaltmaya yönelik çalışmalarına } \\
\text { yardımcı olmak }\end{array}$ & 0,710 & & & 3,8337 \\
\hline Müşterilerime Bütçe vb. finansal planlama çalışmalarında destek vermek & 0,665 & & & 3,5526 \\
\hline $\begin{array}{l}\text { Müşterilerime işletmelerinin yönetimi ile ilgili alacakları kararlarda destek } \\
\text { olacak raporlar hazırlamak }\end{array}$ & 0,583 & & & 3,9118 \\
\hline Mali nitelikteki işlemlerle ilgili olarak bilirkişilik yapmak & 0,547 & & & 3,7824 \\
\hline $\begin{array}{l}\text { Müşterilerimin mali tablolarını analiz edip sonuçları doğrultusunda } \\
\text { tavsiyelerde bulunmak }\end{array}$ & 0,516 & & & 4,1760 \\
\hline $\begin{array}{l}\text { Müşterilerimin mali nitelikteki faaliyetlerini mevzuata uygun olarak } \\
\text { gerçekleştirip gerçekleştirmediği hususunda inceleme ve denetim yapmak }\end{array}$ & 0,511 & & & 3,9707 \\
\hline $\begin{array}{l}\text { Müşterilerimin faaliyet sonuçlarının ilgili tüm taraflara (yatırımcı, kredi } \\
\text { kuruluşları vb.) doğru ve tarafsız bir şekilde açıklanmasını sağlamak }\end{array}$ & 0,505 & & & 4,1247 \\
\hline Müşterilerime yatırım, finansman vb. kararlarında tavsiyelerde bulunmak & 0,475 & & & 3,8753 \\
\hline Faktör 2: Yasal Yükümlülükleri Yerine Getirme Rolü & & 19,500 & $\mathbf{0 , 8 7 0}$ & \\
\hline $\begin{array}{l}\text { Müşterilerimin vergi idaresine karşı sorumluluklarını yerine getirmelerine } \\
\text { yardımcı olmak }\end{array}$ & 0,824 & & & 4,3130 \\
\hline $\begin{array}{l}\text { Müşterilerimin Sosyal Güvenlik Kurumuna karşı sorumluluklarını yerine } \\
\text { getirmelerine yardımcı olmak }\end{array}$ & 0,815 & & & 4,2763 \\
\hline $\begin{array}{l}\text { Müşterilerimin mali nitelik taşıyan faaliyetlerinin Genel Kabul Görmüş } \\
\text { Muhasebe İlkeleri doğrultusunda muhasebeleştirilmesi ve mali tablolarının } \\
\text { hazırlanmasını sağlamak }\end{array}$ & 0,754 & & & 4,4425 \\
\hline $\begin{array}{l}\text { Müşterilerimin her türlü mali işlemlerinin mevzuata uygun şekilde } \\
\text { yapılmasını sağlamak }\end{array}$ & 0,681 & & & 4,3178 \\
\hline
\end{tabular}




\begin{tabular}{|l|c|c|c|c|}
\hline $\begin{array}{l}\text { Müşterilerime işletmelerinin muhasebe sistemlerinin kurulması ve } \\
\text { geliştirilmesinde yardımcı olmak }\end{array}$ & 0,655 & & & 4,2200 \\
\hline Müşterilerime mali mevzuat ile ilgili konularda danışmanlık yapmak & 0,634 & & & 4,2689 \\
\hline Faktör 3: Asli Görev Dışındaki İşler Rolü & & $\mathbf{1 0 , 9 0 7}$ & $\mathbf{0 , 7 5 1}$ & \\
\hline $\begin{array}{l}\text { Müşterilerimin resmi kurumlarla ilişkili olarak kişisel iş ve işlemlerine } \\
\text { yardımcı olmak }\end{array}$ & 0,847 & & & 3,3374 \\
\hline $\begin{array}{l}\text { Müşterilerimin diğer her türlü bürokratik işlemlerini takip edip } \\
\text { gerçekleştirmelerine yardımcı olmak }\end{array}$ & 0,780 & & & 2,8925 \\
\hline $\begin{array}{l}\text { Müş̧terilerimin bağlı bulundukları meslek odalarına karşı sorumluluklarını } \\
\text { yerine getirmelerine yardımcı olmak }\end{array}$ & 0,657 & & 3,8240 \\
\hline KMO Measure of Sampling Adequacy: 0,871, Bartlett's Test Chi-Square: 4461,617 Sig.: 0,000 & \\
\hline
\end{tabular}

Tablo 2'de görüldüğü gibi ankette yer alan 21 soru üç faktör altında toplanmıştır. Soruların gruplanmasına göre faktörler isimlendirilmiş ve muhasebe meslek mensuplarının daha çok işletmelere finansal konularda karar desteği sağlamak amacıyla gerçekleştirdikleri işlemlere ait ifadeler birinci faktör "Mali Danışmanlık Rolü” altında toplanmıştır. İşletmelerin devlete karşı yasal sorumluluklarını yerine getirmelerine yardımcı olmak amacıyla gerçekleştirdikleri işlemlere ait ifadeler ikinci faktör "Yasal Yükümlülükleri Yerine Getirme Rolü” altında toplanmıştır. Müşterilerin diğer kişisel taleplerini karşılamaya yönelik olan ve yasal görev tanımında yer almayan işlere ait ifadeler ise Faktör 3: “Asli Görev Dışındaki İşler Rolü” olarak adlandırılmıştır. Ankette yer alan 21 ifadenin büyük çoğunluğu birinci faktör altında toplanmıştır ve Faktör 1 toplam varyansın \%25,587'sini açıklamaktadır. Diğer yandan 3 faktör altında gruplanan ifadelere katılımcıların verdiği cevapların ortalamalarına bakıldığında en yüksek değerlerin faktör 2 altındaki ifadelere ait olduğu görülmektedir.

\subsubsection{ANOVA Testi}

Muhasebe meslek mensuplarının 3 ana başlıkta gruplanan mesleki rollerini algılamaları ile demografik özellikleri arasında anlamlı ilişkilerin bulunup bulunmadığını belirlemek için ANOVA testi yapılmıştır. ANOVA testi sonrasında elde edilen bulgular toplu olarak Tablo 3'de gösterilmiştir.

Tablo 3. Demografik Özellikler ile Mesleki Rol Algısı Arasındaki İlişkiler

\begin{tabular}{|l|l|c|c|c|}
\hline & Cinsiyet & Ortalama & F & Anlamlılık \\
\hline Faktör 1: & Erkek & 3,8023 & 0,111 & 0,739 \\
Mali Danışmanlık Rolü & Kadın & 3,8140 & & \\
\hline Faktör 2: & Erkek & 4,3333 & 1,690 & 0,194 \\
Yasal Yükümlülükleri Yerine Getirme Rolü & Kadın & 4,2222 & & \\
\hline Faktör 3: & Erkek & 3,315 & 1,246 & 0,265 \\
Asli Görev Dışındaki İşler Rolü & Kadın & 3,4781 & & \\
\hline & Medeni Hal & Ortalama & F & Anlamlılık \\
\hline Faktör 1: & Bekar & 3,7871 & 0,217 & 0,641 \\
Mali Danışmanlık Rolü & Evli & 3,8111 & & \\
\hline Faktör 2: & Bekar & 4,1340 & 8,835 & $\mathbf{0 , 0 0 3}$ \\
\cline { 2 - 6 }
\end{tabular}




\begin{tabular}{|l|l|c|c|c|} 
Yasal Yükümlülükleri Yerine Getirme Rolü & Evli & 4,3637 & & \\
\hline Faktör 3: & Bekar & 3,3268 & 0,453 & 0,501 \\
Asli Görev Dışındaki İşler Rolü & Evli & 3,3638 & & \\
\hline & Yaş & Ortalama & F & Anlamlılık \\
\hline Faktör 1: & $20-35$ & 3,8261 & 0,641 & 0,528 \\
Mali Danışmanlık Rolü & $36-50$ & 3,7738 & & \\
& 51 ve üzeri & 3,8173 & & \\
\hline Faktör 2: & $20-35$ & 4,2538 & 1,545 & 0,214 \\
Yasal Yükümlülükleri Yerine Getirme Rolü & $36-50$ & 4,3474 & & \\
& 51 ve üzeri & 4,3764 & & \\
\hline Faktör 3: & $20-35$ & 3,4010 & 0,272 & 0,762 \\
Asli Görev Dışındaki İşler Rolü & $36-50$ & 3,3117 & & \\
& 51 ve üzeri & 3,3099 & & \\
\hline
\end{tabular}

\begin{tabular}{|l|l|l|l|l|}
\hline & Eğitim & Ortalama & F & Anlamlılık \\
\hline Faktör 1: & Lise & 3,7500 & 0,742 & 0,527 \\
Mali Danışmanlık Rolü & Ön Lisans & 3,7029 & & \\
& Lisans & 3,8377 & & \\
& Lisansüstü & 3,7255 & & \\
\hline Faktör 2: & Lise & 4,2806 & 0,815 & 0,486 \\
Yasal Yükümlülükleri Yerine Getirme Rolü & Ön Lisans & 4,1377 & & \\
& Lisans & 4,3409 & & \\
& Lisansüstü & 4,2745 & & \\
\hline Faktör 3: & Lise & $3,6944 *$ & 5,586 & $\mathbf{0 , 0 0 1}$ \\
Asli Görev Dışındaki İşler Rolü & Ön Lisans & 3,2681 & & \\
& Lisans & $3,3123 *$ & & \\
& Lisansüstü & 3,0980 & & \\
\hline Faktör 1: & Unvan & Ortalama & F & Anlamlılık \\
Mali Danışmanlık Rolü & SM & 3,6989 & 5,199 & $\mathbf{0 , 0 2 3}$ \\
\hline Faktör 2: & SMMM & 3,8426 & & \\
Yasal Yükümlülükleri Yerine Getirme Rolü & SM & 4,1579 & 1,243 & 0,266 \\
\hline Faktör 3: & SMMM & 4,3403 & & \\
Asli Görev Dışındaki İşler Rolü & SMMM & 3,4342 & 0,271 & 0,603 \\
\hline & Deneyim & 3,3363 & & \\
\hline Faktör 1: & $0-10$ & Ortalama & F & Anlamlılık \\
Mali Danışmanlık Rolü & $11-20$ & 3,8236 & 0,411 & 0,663 \\
& 21 yıl ve üzeri & 3,7858 & & \\
\hline Faktör 2: & $0-10$ & 3,7984 & & \\
Yasal Yükümlülükleri Yerine Getirme Rolü & $11-20$ & 4,2370 & 2,239 & 0,108 \\
& 21 yıl ve üzeri & 4,3674 & & \\
\hline Faktör 3: & $0-10$ & 3,3506 & & \\
Asli Görev Dışındaki İşler Rolü & $11-20$ & 3,3574 & 0,141 & 0,869 \\
& 21 yıl ve üzeri & 3,3605 & & \\
\hline & Gelir Düzeyi & Ortalama & F & Anlamlılık \\
\hline
\end{tabular}




\begin{tabular}{|c|c|c|c|c|}
\hline $\begin{array}{l}\text { Faktör 1: } \\
\text { Mali Danışmanlık Rolü }\end{array}$ & $\begin{array}{l}\text { 5000TL'den az } \\
\text { 5000TL'den fazla }\end{array}$ & $\begin{array}{l}3,7765 \\
3,9564\end{array}$ & 5,364 & 0,021 \\
\hline Faktör 2: & 5000TL'den az & 4,2960 & 0,084 & 0,772 \\
\hline Yasal Yükümlülükleri Yerine Getirme Rolü & 5000TL'den fazla & 4,3615 & & \\
\hline \multirow{3}{*}{$\begin{array}{l}\text { Faktör 3: } \\
\text { Asli Görev Dışındaki İşler Rolü }\end{array}$} & 5000TL'den az & 3,3207 & 1,378 & 0,241 \\
\hline & 5000TL'den fazla & 3,5365 & & \\
\hline & $\begin{array}{l}\text { İşyerindeki } \\
\text { Pozisyonu }\end{array}$ & Ortalama & $\mathbf{F}$ & Anlamlılık \\
\hline Faktör 1: & İşyeri Sahibi & 3,8282 & 1,336 & 0,248 \\
\hline Mali Danışmanlık Rolü & Çalışan & 3,7134 & & \\
\hline Faktör 2: & İşyeri Sahibi & 4,3333 & 1,433 & 0,232 \\
\hline Yasal Yükümlülükleri Yerine Getirme Rolü & Çalışan & 4,1992 & & \\
\hline $\begin{array}{l}\text { Faktör 3: } \\
\text { Asli Görev Dışındaki İşler Rolü }\end{array}$ & $\begin{array}{l}\text { İşyeri Sahibi } \\
\text { Çalışan }\end{array}$ & $\begin{array}{l}3,3405 \\
3,4106\end{array}$ & 0,031 & 0,861 \\
\hline
\end{tabular}

* Ortalama farkları \% 5 anlamlılık seviyesinde istatistiki olarak anlamlıdır.

Muhasebe meslek mensuplarının mesleki rollerini algılamaları ile demografik özellikleri arasındaki ilişkiyi tespit etmek amacıyla yapılan bu analiz sonuçlarına göre anlamlı ilişkilere ait bulgular aşağıdaki şekildedir.

İlk olarak, muhasebe meslek mensuplarının medeni hali ile faktör 2 arasında anlamlı bir ilişki (Anlamlılık Değeri 0,003) bulunmaktadır. Yasal yükümlülükleri yerine getirme rolüne evli olan katılımcıların vermiş oldukları cevapların ortalamaları $(4,3637)$ bekar olanlara $(4,1340)$ göre daha yüksektir. Yani evli muhasebe meslek mensupları mesleki rollerini daha fazla yasal yükümlülükleri yerine getirme boyutunda algilamaktadırlar.

İkinci olarak, muhasebe meslek mensuplarının eğitim düzeyi ile faktör 3 arasında anlamlı bir ilişki (Anlamlılık Değeri 0,001) tespit edilmiştir. Bu ilişkinin hangi değişkenler arasında olduğunu belirlemek amacıyla yapılan Post Hoc (Tukey) testine göre lise mezunu olan muhasebe meslek mensupları ile üniversite mezunu muhasebe meslek mensupları arasında fark olduğu görülmektedir. Asli görev dışındaki işler rolü olarak adlandırılan ve meslek mensuplarının yasal görev tanımları ve mesleki yetkinlikleri dışındaki kalan işleri mesleki rolü olarak algılama noktasında lise mezunları $(3,6944)$ üniversite mezunlarına $(3,3123)$ göre daha yüksek oranda cevap vermişlerdir. Başka bir ifadeyle lise mezunu muhasebe meslek mensupları asli görevleri dışında olan ve müşterilerinin kendi kişisel sorumluluğundaki bürokratik işleri onların yerine yapmayı daha fazla oranda mesleki rolleri olarak algılamaktadırlar. Ayrıca lisansüstü eğitim seviyesindeki muhasebe meslek mensuplarının bu role ilişkin cevaplarının ortalamaları $(3,0980)$ daha da düşüktür. Bu da göstermektedir ki muhasebe meslek mensuplarının eğitim seviyesi yükseldikçe mesleki rollerini faktör 3 boyutunda algilamaları azalmaktadır.

Üçüncü olarak, mesleki unvan ile faktör 1 arasında anlamlı bir ilişki (Anlamlılık Değeri 0,023) belirlenmiştir. Türkiye'de muhasebeciler ya Serbest Muhasebeci (SM) ya 
da Serbest Muhasebeci Mali Müşavir (SMMM) olarak mesleklerini icra etmektedirler. Uygulamada Türkiye'deki her iki ünvana sahip muhasebe meslek mensupları da benzer iş ve işlemleri gerçekleştirmektedirler. Mesleki rollerini mali danışmanlık boyutunda görmek açısından SMMM'lerin cevaplarının ortalamalarının $(3,8426)$ SM'lere göre $(3,6989)$ daha yüksek olduğu tespit edilmiştir. Yani SMMM ünvanına sahip meslek mensupları mesleki rollerini daha çok mali danışmanlık boyutunda algılamaktadırlar. $\mathrm{Bu}$ sonuç eğitim seviyesi düşük olan (lise mezunu) muhasebe meslek mensuplarının mesleki rollerini daha yüksek oranda faktör 3 boyutunda algılamaları sonucu ile uyum göstermektedir.

Son olarak muhasebe meslek mensuplarının gelir düzeyi ile faktör 1 arasında anlamlı bir ilişki (Anlamlılık Değeri 0,021) tespit edilmiştir. Daha yüksek gelir düzeyine sahip muhasebe meslek mensuplarının mesleki rollerini mali danışmanlık boyutunda algılamaları daha fazladır. Çünkü yüksek gelir düzeyinde bulunan muhasebe meslek mensuplarının mali danışmanlık rolü boyutundaki ifadelere verdikleri cevapların ortalamaları $(3,9564)$ düzeyindedir.

Yukarıda bahsedilenler dışında muhasebe meslek mensuplarının cinsiyet, yaş ve işyerindeki pozisyonları açısından mesleki rollerini algılamalarında herhangi bir anlamlı ilişki bulunmamaktadır.

Özetle muhasebe meslek mensuplarının demografik özellikleri ile mesleki rollerini algılamaları arasında anlamlı bir ilişki vardır (H1) hipotezi; medeni hali ile yasal yükümlülükleri yerine getirme rolü boyutunda, eğitim düzeyleri ile asli görev dışındaki işler rolü boyutunda ve son olarak mesleki unvan ve gelir düzeyi ile mali danışmanlık rolü boyutunda kabul edilmiştir.

\section{SONUÇ}

Her meslekte olduğu gibi muhasebe mesleğinde de meslek mensuplarının mesleki rolleri zaman içerisinde farklılaşmakta ve değişmektedir. Bu farklılaşmada etkili olan başlıca faktörler muhasebe meslek mensupları arasındaki rekabet ve müşteri ihtiyaç ve beklentilerinin artmasıdır. Her ülkede olduğu gibi Türkiye'de de muhasebe meslek mensuplarının görev ve sorumlulukları yasalarla belirlenmiştir. Ancak yasada tanımlanan görevlerin yanı sıra muhasebe meslek mensuplarının bazen almış olduğu eğitim ve mesleki nitelikleri ile hiçbir ilgisi olmayan bazı görevleri de üstlenmek zorunda kalmaktadirlar. Bu durum meslek mensuplarının mesleki rollerinde bir belirsizlik yaratmaktadır. Günlük çalışmanın bir parçası olarak sürekli yapılan bu iş ve görevler zamanla muhasebe meslek mensuplarının asli rolü gibi algılanabilmektedirler. Muhasebe meslek mensuplarının mesleki rollerini tartışmaya açmak düşüncesiyle bu çalışmada meslek mensuplarının mesleki rollerini nasıl algıladıkları ve bu algıları ile demografik özelliklerinin bir ilişkisinin olup almadığı araştırılmıştır. Bu amaca ulaşmak için muhasebe meslek mensuplarıyla yapılan anketler analiz edilmiştir. 
Yapılan analizler sonucunda muhasebe meslek mensuplarının mesleki rolleri 3 boyutta gruplandırılmıştır. Faktör analiziyle elde edilen bu boyutlar muhasebecilerin mesleki rol tanımları olarak kabul edilmiştir. Ortaya çıkan boyutlar, o faktör altında toplanan ifadeler göz önüne alınarak Faktör 1: Mali Danışmanlık Rolü, Faktör 2: Yasal Yükümlülükleri Yerine Getirme Rolü ve Faktör 3: Asli Görev Dışındaki İşler Rolü olarak adlandırılmıştır.

Yapılan ANOVA testleri sonucunda; evli muhasebe meslek mensuplarının bekarlara göre mesleki rollerini daha fazla yasal yükümlülükleri yerine getirme boyutunda, eğitim düzeyi lise olan muhasebe meslek mensuplarının üniversite mezunu olanlara göre mesleki rollerini daha fazla oranda asli görevi dışındaki işler rolü boyutunda algıladıkları tespit edilmiştir. Diğer taraftan SMMM unvanına sahip olan ile gelir düzeyi yüksek olan muhasebe meslek mensuplarının ise mesleki rollerini daha fazla oranda mali danışmanlık rolü boyutunda algıladıkları sonucuna ulaşılmıştır.

Ayrıca 21 ifadeye verilen cevapların ortalama değerlerine göre muhasebe meslek mensuplarının genel itibariyle yasal yükümlülükleri yerine getirme rolüne ilişkin ifadelere daha yüksek oranda katılım yönünde cevap verdikleri görülmüştür.

Özetle muhasebe meslek mensuplarının eğitim düzeyi ve geliri arttıkça mesleki rollerini daha fazla mali danışmanlık boyutunda algıladıkları, eğitim düzeyi düştüğünde ise bu algılamanın asli görevler dışındaki işler boyutuna doğru değiştiği tespit edilmiştir. Bu sonuçların beklenen bir durum olduğunu söylemek mümkündür. Çünkü muhasebe meslek mensuplarının eğitim düzeyi yüksek olduğu zaman işletmelere mali danışmanlık yapma konusundaki yetkinlikleri de artmaktadır. Böylece hem asli görevi olmayan detay ve gereksiz işlerden uzaklaşmaktalar hem de işletmelere sağladıkları nitelikli mali danışmanlık hizmeti ile daha fazla gelir elde etmektedirler. Diğer taraftan eğitim düzeyi düşük muhasebe meslek mensupları ise mali danışmanlık yapmak gibi daha fazla bilgi ve nitelik gerektiren işlerden çok, müşterilerinin şahsi işlerini yerine getirmekle zamanlarının önemli bölümünü harcamaktadırlar. Böylece müşteri memnuniyetlerini bu şekilde sağlamaktalar ancak çoğunlukla küçük işletmelere hizmet sunabilmektedirler.

Türkiye'de muhasebe meslek mensuplarının müşterilerinin kişisel iş ve işlemlerini onların adına yerine getirmek zorunda kaldıkları bilinen bir gerçektir. Bu durum muhasebecilik mesleğinin kalitesini düşürmekte ve toplumdaki algılanmasını da olumsuz yönde etkilemektedir. Literatürde toplumun muhasebecilik mesleğini nasıl algıladığı ile ilgili çalışmalar bulunmakla birlikte, doğrudan meslek mensuplarının kendi mesleki rollerini nasıl algıladıklarına yönelik herhangi bir araştırmaya rastlanamamaktadır. Bu açıdan bu ve gelecekte yapılacak benzer araştırmalardan elde edilen sonuçlar muhasebe meslek mensuplarının kendi mesleki rol algılamalarını gözden geçirmeleri açısından faydalı olacaktır. Ayrıca TÜRMOB gibi muhasebe meslek örgütlerinin de meslekle ilgili olumsuz algıları önleyecek ve mesleğin toplumdaki algısını olumlu yönde değiştirecek adımlar atması noktasında katkı sağlayacaktır. 


\section{KAYNAKLAR}

Aydın, İnayet (2002), “İş Yaşamında Stres”, 2. Baskı, Ankara, Pagem A Yayıncılık, s.41.

Başar, Hüseyin (1998), "Eğitim Denetçisi Rolleri, Yeterlikleri ve Yetiştirilmesi”, Ankara, Pegem Yayıncılık, s. 23.

Başaran, İbrahim Ethem (1991), “Örgütsel Davranış”, 2. Basım, Ankara, A.Ü. Eğitim Fakültesi Yayını, s.132-135.

Ceylan, Adnan - Yıldırım Hüseyin Ulutürk (2006), "Rol Belirsizliğii, Rol Çatışması, İş Tatmini ve Performans Arasındaki İlişkiler, Doğuş Üniversitesi Dergisi, 7(1), s.49.

Eisenberger, Robert - Huntıngton, Robin - Hutchıson, Steven - Sowa Debora (1986), “Perceived Organizational Support”, Journal of Applied Psychology, 7: s. 502.

Erdoğan, İlhan. (1996), "İşletme Yönetiminde Örgütsel Davranış”, İstanbul, İşletme Fakültesi Yayını, s.2.

Gümüştekin, Gülten Eren ve A. Bircan Öztemiz (2015), “Örgütlerde Stresin Verimlilik ve Performansla Etkileşimi” C:14, S:1, s. 274.

Marşab, Beyhan (1996), "Muhasebe Mesleği Fonksiyonları ve Meslek Mensuplarının Nitelikleri”, Yaklaşım Dergisi, Sayı: 37, s.119.

Nalbantoğlu, Rıfat (2003), "Muhasebe Uygulamaları Konusunda Meslek Mensuplarının Bakış Açıları”, VI. Muhasebe Denetimi Sempozyumu (16 - 19 Nisan 2003).

Nunnally Jum C. - Bernstein Ira H (1994), “Psychometric Theory”, New York, NY: McGraw-Hill.

TURMOB, (2017) Üye İstatistikleri, Meslek Mensubu Dağılım Tablosu (SM-SMMM), (http://http://turmob.org.tr/TurmobWeb/Kurumsal/UyeIstatistikleri, 17.01.2017).

Yazıcıoğlu, Yahşi - Erdoğan, Saniye (2004), "SPSS Uygulamalı Bilimsel Araştırma Yöntemleri”, Ankara, Detay Yayıncılık. 